\title{
Dissemination of the mcr-1 colistin resistance gene
}

Citation for published version (APA):

Arcilla, M. S., van Hattem, J. M., Matamoros, S., Melles, D. C., Penders, J., de Jong, M. D., \& Schultsz, C. (2016). Dissemination of the mcr-1 colistin resistance gene. Lancet Infectious Diseases, 16(2), 147-149. https://doi.org/10.1016/S1473-3099(15)00541-1

Document status and date:

Published: 01/01/2016

DOI:

10.1016/S1473-3099(15)00541-1

Document Version:

Publisher's PDF, also known as Version of record

Document license:

Taverne

Please check the document version of this publication:

- A submitted manuscript is the version of the article upon submission and before peer-review. There can be important differences between the submitted version and the official published version of record.

People interested in the research are advised to contact the author for the final version of the publication, or visit the DOI to the publisher's website.

- The final author version and the galley proof are versions of the publication after peer review.

- The final published version features the final layout of the paper including the volume, issue and page numbers.

Link to publication

\footnotetext{
General rights rights.

- You may freely distribute the URL identifying the publication in the public portal. please follow below link for the End User Agreement:

www.umlib.nl/taverne-license

Take down policy

If you believe that this document breaches copyright please contact us at:

repository@maastrichtuniversity.nl

providing details and we will investigate your claim.
}

Copyright and moral rights for the publications made accessible in the public portal are retained by the authors and/or other copyright owners and it is a condition of accessing publications that users recognise and abide by the legal requirements associated with these

- Users may download and print one copy of any publication from the public portal for the purpose of private study or research.

- You may not further distribute the material or use it for any profit-making activity or commercial gain

If the publication is distributed under the terms of Article $25 \mathrm{fa}$ of the Dutch Copyright Act, indicated by the "Taverne" license above, 
College of Medicine, Zhejiang University, Hangzhou, China (YFH, FL, GFG, BLZ); Beijing Key Laboratory of Microbial Drug Resistance and Resistome, Beijing, China (YFH, FL, BLZ); and Chinese Center for Disease Control and Prevention, Beijing, China (GFG)

1 Liu Y-Y, Wang Y, Walsh RT et al. Emergence of plasmid-mediated colistin resistance mechanism MCR-1 in animals and human beings in China: a microbiological and molecular biological study. Lancet Infect Dis 2015. http://dx.doi.org/10.1016/S14733099(15)00424-7.

2 Li J, Jia H, Cai X et al. An integrated catalog of reference genes in the human gut microbiome. Nat Biotechnol 2014; 32: 834-41.

3 Qin J, Li Y, Cai Z et al. A metagenome-wide association study of gut microbiota in type 2 diabetes. Nature 2012; 490: 55-60.

4 Hu Y, Yang X, Qin J et al. Metagenome-wide analysis of antibiotic resistance genes in a large cohort of human gut microbiota. Nat Commun 2013; 4: 2151.

5 Smillie CS, Smith MB, Friedman J, Cordero OX, David LA, Alm EJ. Ecology drives a global network of gene exchange connecting the human microbiome. Nature 2011; 480: 241-44.

In their Comment on the Article by Yi-Yun Liu and colleagues about the emergence of plasmid-mediated colistin resistance involving the $\mathrm{mcr}-1$ gene from bacteria isolated in China, ${ }_{1}$ David Paterson and Patrick Harris ${ }^{2}$ referred to our finding of colistin resistance in two Escherichia coli isolates from a pig and a human being in Laos that were indistinguishable by pulsed-field gel electrophoresis. ${ }^{3}$ Our results, suggested animal to human transmission for which no known chromosomally encoded colistin resistance mechanisms were identified, raising the question of a similar mechanism of colistin resistance to that identified by Liu and colleagues. We screened for the presence of the mor-1 gene in these isolates along with other colistin-resistant $E$ coli isolates from several countries (Laos, Thailand, France, and Nigeria) from human beings and pigs (only in Laos) ${ }^{4}$ and in poultry from Algeria using PCR and sequencing as described by Liu and colleagues (table). ${ }^{1}$ We included as controls a colistin-susceptible revertant $E$ coli strain (obtained at the 18th passage in colistin-free medium) from a pig $^{3}$ and 12 colistin-susceptible $E$ coli strains isolated from the same stool samples from which the colistinresistant $E$ coli strains were isolated. $12(63 \%)$ of 19 colistin-resistant $E$ coli strains tested were positive for the mcr-1 gene and sequences were $100 \%$ identical to that of $\mathrm{mcr}-1$ gene sequence reported by Liu and colleagues (table). ${ }^{1}$ These include $E$ coli strains from Laos (from asymptomatic people and pigs including the strain transferred from a pig to a farmer), Thailand (asymptomatic people), and from Algeria (chickens). None of the 12 colistin-susceptible $E$ coli strains and the colistin-susceptible revertant strain (the parent resistant strain was positive for mcr-1) were positive for mcr-1. The susceptible revertant isolate has probably lost the resistance by loss of a plasmid that is under investigation. We clearly show that plasmid-mediated colistin resistance has spread beyond China to the neighbouring southeast Asian countries and even further to Africa where colistin is widely used in animal production. We anticipate that with the extensive use of colistin in animal production, including in Europe, ${ }^{5}$ plasmid-mediated colistin resistance has already spread worldwide, and this calls for prompt international action to restrict or ban the use of colistin in agriculture to avoid further spread of resistance, as occurred with NDM-1 5 years ago.

We declare no competing interests.

\section{Abiola Olumuyiwa Olaitan,} Selma Chabou, Liliane Okdah, Serge Morand, *Jean-Marc Rolain jean-marc.rolain@univ-amu.fr

Aix-Marseille Université, URMITE, 13385 Marseille Cedex 5, France (AOO, SC, LO, J-MR); Institut des Sciences de l'Evolution, CNRS-IRD-UM2, CC065, Montpellier, France (SM); and CNRS-CIRAD, Centre d'Infectiologie Christophe Mérieux du Laos, Vientiane, Lao PDR (SM)

1 Liu YY, Wang Y, Walsh TR, et al. Emergence of plasmid-mediated colistin resistance mechanism MCR- 1 in animals and human beings in China: a microbiological and molecular biological study. Lancet Infect Dis; published online $18 \mathrm{Nov}$. http://dx.doi. org/10.1016/S1473-3099(15)00424-7.

2 Paterson DL, Harris PN. Colistin resistance: a major breach in our last line of defence. Lancet Infect Dis; published online Nov 18. http:// dx.doi.org/10.1016/S1473-3099(15)00463-6.

\begin{tabular}{|c|c|c|c|c|c|}
\hline & $\begin{array}{l}\text { Colistin minimum } \\
\text { inhibitory concentration } \\
\text { (mg/L) }\end{array}$ & Year & Source & Country & $m c r-1$ \\
\hline LH30 & 6 & 2012 & Human & Laos & + \\
\hline LH57 & 8 & 2012 & Human & Laos & + \\
\hline $\mathrm{LH} 1$ & 6 & 2012 & Human & Laos & + \\
\hline LH121 & 16 & 2012 & Human & Laos & + \\
\hline LH140 & 12 & 2012 & Human & Laos & + \\
\hline LH257 & 12 & 2012 & Human & Laos & + \\
\hline P10 & 6 & 2012 & Pig & Laos & + \\
\hline P6 & 6 & 2012 & Pig & Laos & + \\
\hline P17 & 4 & 2012 & Pig & Laos & + \\
\hline P7 & 4 & 2012 & Pig & Laos & - \\
\hline TH176 & 6 & 2012 & Human & Thailand & - \\
\hline $\mathrm{TH} 214$ & 6 & 2012 & Human & Thailand & + \\
\hline TH99 & 4 & 2012 & Human & Thailand & + \\
\hline FHM19* & 12 & 2012 & Human & France & - \\
\hline $\mathrm{FHA} 102 \dagger$ & 12 & 2012 & Human & France & - \\
\hline FHA113‡ & 12 & 2012 & Human & France & - \\
\hline $\mathrm{NH} 94 \mathrm{~S}$ & 12 & 2012 & Human & Nigeria & - \\
\hline 235 & 4 & 2015 & Chicken & Algeria & + \\
\hline 249 & 3 & 2015 & Chicken & Algeria & - \\
\hline \multicolumn{6}{|c|}{$\begin{array}{l}\text { Mutations in PmrB sensor kinase of the two-component system: *Pro7_Gln12del } \\
\text { (deletion of } 6 \text { aminoacids); †Ala159Val; †Thr156Lys; and Slso92 ins (insertion of } \\
\text { isoleucine at position 92). }\end{array}$} \\
\hline $\begin{array}{l}\text { Table: Colis } \\
\text { isolated fro }\end{array}$ & $\begin{array}{l}\text { in-resistant Escherichia coli } \\
\text { m different sources }\end{array}$ & with th & associated & d mcr-1 ger & \\
\hline
\end{tabular}

3 Olaitan $\mathrm{AO}$, Thongmalayvong $\mathrm{B}$, Akkhavong $\mathrm{K}$, et al. Clonal transmission of a colistin-resistant Escherichia coli from a domesticated pig to a human in Laos. J Antimicrob Chemother 2015 70:3402-04.

4 Olaitan AO, Morand S, Rolain JM. Emergence of colistin-resistant bacteria in humans without colistin usage: a new worry and cause for vigilance. Int J Antimicrob Agents (in press).

5 Kempf I, Fleury MA, Drider D, et al. What do we know about resistance to colistin in Enterobacteriaceae in avian and pig production in Europe? Int J Antimicrob Agents 2013; 42: 379-83.

Plasmid-mediated transferable colistin resistance encoded by the $\mathrm{mcr}-1$ gene was described in Escherichia coli and Klebsiella pneumoniae isolates from pigs and chicken at a prevalence of around $20 \%$, and in clinical isolates from human beings at a prevalence of around $1 \%$ in China. ${ }^{1}$ The prevalence of the mcr-1 gene in Enterobacteriaceae in other countries and in the community is unknown.

We did a prospective study of acquisition of fecal colonisation and carriage with extended-spectrum

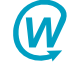

Published Online December 17, 2015 http://dx.doi.org/10.1016/ S1473-3099(15)00540-X

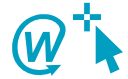

Published Online December 17, 2015 http://dx.doi.org/10.1016/ S1473-3099(15)00541-1

This online publication has been corrected. The corrected version first appeared at thelancet.com/ infection on Jan 25, 2015 


\section{Correspondence}

\begin{tabular}{|c|c|c|c|c|c|c|}
\hline & Traveller with isolate 1 & Traveller with isolate 2 & Traveller with isolate 3 & Traveller with isolate 4 & Traveller with isolate 5 & Traveller with isolate 6 \\
\hline Travel destination & $\begin{array}{l}\text { Thailand, Vietnam, } \\
\text { Cambodia, Laos }\end{array}$ & Tunisia & Peru, Bolivia, Colombia & China & China & Peru, Bolivia \\
\hline Travel duration (days) & 21 & 8 & 40 & 14 & 23 & 22 \\
\hline Age (years) & 56 & 55 & 25 & 54 & 62 & 26 \\
\hline Sex & Female & Female & Female & Male & Female & Male \\
\hline ESBL gene (ESBL group) & $\begin{array}{l}\text { CTX-M-14 } \\
\text { (CTX-M group 9) }\end{array}$ & $\begin{array}{l}\text { CTX-M-1 } \\
\text { (CTX-M group 1) }\end{array}$ & $\begin{array}{l}\text { CTX-M-15 } \\
\text { (CTX-M group 1) }\end{array}$ & $\begin{array}{l}\text { CTX-M-65 } \\
\text { (CTX-M group 9) }\end{array}$ & $\begin{array}{l}\text { CTX-M-55 } \\
\text { (CTX-M group 1) }\end{array}$ & $\begin{array}{l}\text { CTX-M-55 } \\
\text { (CTX-M group 1) }\end{array}$ \\
\hline \multicolumn{7}{|c|}{ Minimum inhibitory concentration of antimicrobial drug $(\mathrm{mg} / \mathrm{L})^{*}$} \\
\hline Amoxicillin-clavulanic acid & 16 & 8 & $>16$ & 16 & 8 & 4 \\
\hline Piperacillin-tazobactam & 8 & $\leq 4$ & 8 & $\leq 4$ & $\leq 4$ & $\leq 4$ \\
\hline Cefotaxime & 16 & 8 & 32 & 16 & $>32$ & $>32$ \\
\hline Cefoxitin & 16 & $\leq 4$ & 8 & $\leq 4$ & $\leq 4$ & $\leq 4$ \\
\hline Ceftazidime & $\leq 1$ & $\leq 1$ & 16 & $\leq 1$ & 4 & 4 \\
\hline Cefepime & 2 & 2 & 2 & $\leq 1$ & 2 & 2 \\
\hline Imipenem & $\leq 0 \cdot 25$ & $\leq 0.25$ & $\leq 0.25$ & $\leq 0 \cdot 25$ & $\leq 0 \cdot 25$ & $\leq 0.25$ \\
\hline Meropenem & $\leq 0.25$ & $\leq 0.25$ & $\leq 0.25$ & $\leq 0.25$ & $\leq 0.25$ & $\leq 0.25$ \\
\hline Gentamicin & $>8$ & $\leq 1$ & $>8$ & $\leq 1$ & $>8$ & $\leq 1$ \\
\hline Tobramycin & 8 & $\leq 1$ & $>8$ & 8 & 8 & $\leq 1$ \\
\hline Nitrofurantoin & 256 & $\leq 16$ & 128 & 32 & 64 & $\leq 16$ \\
\hline Co-trimoxazole & $>8$ & $>8$ & $>8$ & $\leq 1$ & $>8$ & $>8$ \\
\hline Norfloxacin & $>8$ & 8 & $>8$ & 2 & $>8$ & $>8$ \\
\hline Ciprofloxacin & $>2$ & $>2$ & $>2$ & 1 & $>2$ & $>2$ \\
\hline Colistin & 4 & 4 & 4 & 4 & 4 & 8 \\
\hline
\end{tabular}

$\beta$-lactamase (ESBL)-producing Enterobacteriaceae in 2001 Dutch travellers (the COMBAT study), ${ }^{2}$ from November, 2012, to November, 2013. Acquisition was defined as the absence of ESBL-producing Enterobacteriaceae in a fecal swab sample taken immediately before travel and detection of ESBL-producing Enterobacteriaceae in a sample taken within 1-2 weeks after return to the Netherlands. Of 1847 travellers at risk, 633 (34\%) acquired ESBLproducing Enterobacteriaceae. Nine of these 633 travellers acquired ESBL-producing Escherichia coli with a colistin minimum inhibitory concentration of 4-8 mg/L (EUCAST clinical breakpoint for resistance $>2 \mathrm{mg} / \mathrm{L}$ ) as detected using Vitek-2 and confirmed by E-test. After publication of the report by Yi-Yun Liu and colleagues, ${ }^{1}$ these nine isolates were tested by $\mathrm{PCR}^{1}$ for the presence of the mcr-1 gene. The gene was detected in six of nine isolates and sequencing of the amplicons showed a $100 \%$ homology over the length of the fragments with the published sequence. ${ }^{1}$ Three ESBL-producing E coli were mcr-1 PCR negative, suggesting colistin resistance due to other mechanisms. ${ }^{3}$ Analysis of ESBL genes by microarray, ${ }^{4} \mathrm{PCR}$, and sequencing showed that the mcr-1 positive ESBLproducing E coli carried ESBL genes belonging to multiple groups (table).

Of the six travellers who acquired ESBL-producing E coli carrying the mcr-1 gene, two unrelated travellers visited Peru and Bolivia, two unrelated travellers visited China, one visited Tunisia, and one visited multiple countries in southeast Asia (Thailand, Vietnam, Laos, and (ambodia). The duration of travel ranged between 8 and 40 days (mean 21.3 days). None of the travellers had accessed medical care and none had used antimicrobial drugs during travel, while five had experienced traveller's diarrhoea. Analysis of subsequent fecal samples collected at $1,3,6$, and 12 months after return to the Netherlands did not show ESBL-producing $E$ coli, suggesting short-term colonisation with colistin resistant ESBL-producing E coli or loss of plasmids carrying ESBL and potentially mcr-1 genes.

Colistin is used as an ultimate refuge antimicrobial drug in the treatment of infections caused by multidrug resistant Gram-negative microorganisms. ${ }^{5}$ Our data suggest a worrisome spread of the mcr-1 gene in $E$ coli in the community across at least three continents. The diversity of ESBL genes present in mcr-1 positive isolates suggests that the mcr-1 gene might be carried on multiple plasmid backbones.

This research was funded by Netherlands Organization for Health, Research and Development (ZonMw; 50-51700-98-120) and EU-H2020 programme (COMPARE, 643476). We declare no competing interests. 
†Maris S Arcilla, †Jarne M van Hattem, Sebastien Matamoros,

Damian C Melles, John Penders, Menno D de Jong, * Constance Schultsz, for the COMBAT consortium $\neq$ schultsz@gmail.com

†Contributed equally

$\ddagger$ Members listed in the appendix

Department of Medical Microbiology and Infectious Diseases, Erasmus University Medical Centre, Netherlands (MSA, DCM); Department of Medical Microbiology (JMvH, SM, MDd), CS) and Department of Global Health-Amsterdam Institute for Global Health and Development (CS), Academic Medical Centre, Amsterdam, Netherlands; and Department of Medical Microbiology (JP), Maastricht University Medical Centre, School for Nutrition, Toxicology and Metabolism and School for Public Health and Primary Care, Maastricht, Netherlands

1 Liu Y-Y, Wang Y, Walsh TR, et al. Emergence of plasmid-mediated colistin resistance mechanism MCR-1 in animals and human beings in China: a microbiological and molecular biological study. Lancet Infect Dis 2015; published online November 18. http:// dx.doi.org/10.1016/S1473-3099(15)00424-7.

2 Arcilla MS, van Hattem JM, Bootsma MC, et al. The carriage of multiresistant bacteria after travel (COMBAT) prospective cohort study: methodology and design. BMC Public Health 2014; 14: 410.

3 Olaitan AO, Morand S, Rolain J-M. Mechanisms of polymyxin resistance: acquired and intrinsic resistance in bacteria. Front Microbiol 2014; 5: 643

4 Card R, Zhang J, Das P, Cook C, Woodford N, Anjum MF. Evaluation of an expanded microarray for detecting antibiotic resistance genes in a broad range of Gram-negative bacterial pathogens. Antimicrob Agents Chemother 2013; 57: 458-65.

5 Giske CG. Contemporary resistance trends and mechanisms for the old antibiotics colistin temocillin, fosfomycin, mecillinam and nitrofurantoin. Clin Microbiol Infect 2015 21: 899-905.

\section{Plasmid-mediated colistin resistance mechanisms: is it time to revise our approach to selective digestive decontamination?}

In November, 2015, Yi-Yun Liu and colleagues ${ }^{1}$ published their observations of the emergence of a plasmid-mediated mechanism for polymixin E (colistin) resistance, MCR-1. They reported its identification in both human and animal
Enterobacteriaceae isolates and documented its high in-vitro horizontal transfer rate $\left(10^{-1}\right.$ to $\left.10^{-3}\right)$. Although the detection rate in human Enterobacteriaceae samples remained low (1.4\% of Escherichia coli and $0.7 \%$ Klebsiella pneumoniae), their prevalence was high in Chinese livestock monitored within this study. ${ }^{1}$ With the potential threat of pan-resistant Gram-negative organisms, the authors support WHO's consideration of colistin as an antimicrobial of crucial importance and emphasise the potential Darwinian selection pressures that have arisen from the growing use of polymixins as growth promoters in agriculture. ${ }^{1}$

The threat of potentiating the emergence of colistin resistant Gramnegative organisms raises several concerns. One of these surrounds the use of colistin as an oral or enteral antimicrobial for selective digestive decontamination, predominantly in the intensive care setting. ${ }^{2-4}$ Selective digestive decontamination in the intensive care unit combines oral or enteral decontamination of the gastrointestinal tract (usually with colistin, tobramycin, and amphotericin B) with a short course, intravenous broad-spectrum antimicrobial (such as a third generation cephalosporin). ${ }^{2}$ This intervention has been shown through meta-analysis of randomised control trials to reduce both mortality (at 28 days) and the occurrence of respiratory tract infections in patients admitted to the intensive care unit. ${ }^{2-4}$

Although the short-term benefits of prophylactic antimicrobial chemotherapy in patients in the intensive care unit have been shown for mortality and respiratory tract infections, data for the longterm effects of this approach to therapy in terms of development of antimicrobial resistance is scarce. This remains a major concern in the literature and has meant that selective digestive decontamination remains controversial and not widely accepted in clinical practice within the UK. ${ }^{2,4,5}$ With the emergence in human beings of plasmidmediated resistance mechanisms for antimicrobials of crucial importance, such as colistin, consideration of the increased selection pressures created by exposure to these antimicrobials in prophylactic regimes must be deemed a priority.

To achieve this, engagement with all clinical specialties to promote clinical leadership of antimicrobial stewardship is crucial. ${ }^{6}$ Effective antimicrobial stewardship must consider the future costs (both financial and therapeutic) of the selection of MCR-1 producing organisms on modern medicine. Although the use of selective digestive decontamination in the short-term might be of benefit for the individual patient in intensive care, we call for greater collaboration between clinical specialties to consider the long-term effects of using colistin as part of this regimen. Moreover, we suggest that the role of surveillance for the development of resistance reservoirs in individuals receiving selective digestive decontamination must be considered as a routine to help with the early detection of the unintended effects of this therapy. ${ }^{7.8}$ Although there is a potential place for the use of selective digestive decontamination, investigation of modified regimens devoid of important antimicrobials is required.

AHH and LSPM have consulted for bioMérieux and LSPM for DNA electronics. JCH and HD have received grants from Astellas Pharmaceuticals. TMR declares no competing interests.

*Timothy Miles Rawson, Luke Stephen Prockter Moore, James Christopher Hatcher, Hugo Donaldson,

Alison Helen Holmes

timothy.rawson07@ic.ac.uk

National Institute for Health Research, Health Protection Research Unit in Healthcare Associated Infections and Antimicrobial Resistance, Imperial College London, Hammersmith Campus, London W12 ONN, UK (TMR, LSPM, AHH); and Imperial College Healthcare NHS Trust, London, UK (JCH, $\mathrm{HD}, \mathrm{AHH})$ 